This is the peer reviewed version of the following article:

Nikolić, N.D., Avramović, L., Ivanović, E.R., Maksimović, V.M., Baščarević, Z., Ignjatović, N., 2019. Comparative morphological and crystallographic analysis of copper powders obtained under different electrolysis conditions. Transactions of Nonferrous Metals Society of China 29, 1275-1284. https://doi.org/10.1016/S10036326(19)65034-X

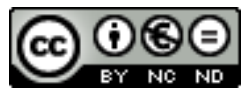

This work is licensed under a Creative Commons Attribution Non Commercial No Derivatives 4.0 license 


\title{
COMPARATIVE MORPHOLOGICAL AND CRYSTALLOGRAPHIC ANALYSIS OF COPPER POWDERS OBTAINED UNDER DIFFERENT ELECTROLYSIS CONDITIONS
}

\author{
Nebojša D. NIKOLIĆ ${ }^{1, *}$, Ljiljana AVRAMOVIĆ ${ }^{2}$, Evica R. IVANOVIĆ3 ${ }^{3}$ Vesna M. \\ MAKSIMOVIĆ $^{4}$, Zvezdana BAŠČAREVIĆ ${ }^{5}$, Nenad IGNJATOVIĆ 6 \\ ${ }^{1}$ ICTM - Department of Electrochemistry, University of Belgrade, Njegoševa 12, Belgrade, \\ Serbia \\ ${ }^{2}$ Mining and Metallurgy Institute, Zeleni bulevar 35, Bor, Serbia \\ ${ }^{3}$ Faculty of Agriculture, University of Belgrade, Nemanjina 6, Belgrade-Zemun, Serbia \\ ${ }^{4}$ Vinča Institute of Nuclear Sciences, University of Belgrade, Belgrade, Serbia \\ ${ }^{5}$ Institute for Multidisciplinary Research, University of Belgrade, Kneza Višeslava 1a, \\ Belgrade, Serbia \\ ${ }^{6}$ Institute of Technical Sciences of the Serbian Academy of Science and Arts, Knez \\ Mihailova 35/IV, Belgrade, Serbia
}

\begin{abstract}
Production of copper powders by the potentiostatic electrolysis under different hydrogen evolution conditions has been investigated. Copper powders were characterized by the scanning electron microscope (SEM), X-ray diffraction (XRD), particle size distribution (PSD), and by determination of the specific surface area (SSA) of the formed powders. Depending on quantity of hydrogen generated during electrolysis, the two types of particles were formed: dendrites and cauliflower-like particles. The dendrites were formed without, while cauliflower-like particles with the quantity of evolved hydrogen enough to achieve strong effect on hydrodynamic conditions in the near-electrode layer. Although macro structure of the particles was very different, they showed similar micro structure. Namely, the both types of the particles consisted of small agglomerates of approximately spherical $\mathrm{Cu}$ grains at the micro level. The existence of the spherical morphology was just responsible for random orientation of $\mathrm{Cu}$ crystallites in the both types of particles. The SSA of cauliflowerlike particles was more than three times larger than the dendrites, while their size was considerably smaller than the dendritic particles. In this way, the useful benefit of $\mathrm{Cu}$ powder formation in the conditions of vigorous hydrogen evolution is shown.
\end{abstract}

Keywords: electrolysis; copper; particles; SEM; XRD; SSA; PSD

\section{Introduction}

Electrolysis is widely used method for synthesis of metals or alloys of the desired characteristics suitable for application in various technologies [1-5]. Morphology of deposits, as the most important characteristic of electrodeposited metals or alloys, depends on the

\footnotetext{
*Corresponding Author: Dr. N.D. Nikolić; E-mail: nnikolic@tmf.bg.ac.rs
} 
regime and parameters of electrolysis. The both constant and periodically changing regimes of electrolysis are used in the electrolysis processes. The parameters affecting the final morphology of electrodeposited metals are: composition and kind of electrolytes, temperature and time of electrolysis, type of working electrode, stirring of the electrolyte, the addition of additives, etc. [1, 6-8]. Aside from the regime and parameters of electrolysis, morphology of deposits is strongly affected by the nature of metals, classifying them into three groups: the normal, intermediate, and inert metals [9].

Thinking to primarily good conductivity, copper has found a wide application in electrical and electronic industries for production of tubes, wires, sheets and for making copper-based alloys [8]. The compact, adherent, bright or powder copper deposits can be obtained by selection of the above mentioned parameters and regimes of electrolysis $[1,6,8$, $10,11]$. The processes of electrolysis in both the potentiostatic [12] and galvanostatic [13, 14] conditions, as well as at periodically changing rate, such as square waves pulsating overpotential (PO) $[1,15]$ and reversing current $(\mathrm{RC})$ regimes $[1,16]$ are widely used for $\mathrm{Cu}$ powder production [1,11-19]. Although the sulfate electrolytes are the most often used, some other types like the nitrate ones are also used [17]. The addition of additives, such as polyvinylpyrrolidone (PVP), sodium dodecyl sulfate (SDS), polyethylene glycol (PEG), cellulose and thiourea (Tu) significantly affect morphology of the particles [16]. Simultaneously, the smaller particles and narrower distribution curves were obtained by electrolysis on platinum than on aluminium electrode [1].

The behaviour of powders as collection of particles is determined by so-called decisive characteristics, such as the specific surface area (SSA), the apparent density, the flowability, and the particle size distribution (PSD) [1, 20]. The shape and size of particles just determine these characteristics of metal powders, irrespective of method of their synthesis.

Morphology of electrolytically produced copper powder is relatively well investigated and systematized in the literature [1, 11-19]. However, the data dealing with crystal structure of copper powders are relatively poor. It was shown recently [21, 22] that there are a strong correlation between morphology and crystal structure of powdered silver obtained by chemical and electrochemical methods of synthesis, with the strong influence on some of decisive characteristics, like the specific surface area. Following this observation, we continue with this type of investigation, with the aim to establish correlation between morphology and crystal structure of copper powders obtained by the potentiostatic regime of electrolysis. Also, the specific surface area (SSA) and the particle size distribution (PSD), as the most important decisive characteristics, of the produced $\mathrm{Cu}$ powders will be examined and correlated with the established dependences. The special attention will be devoted to the effect of hydrogen evolution as the parallel reaction to $\mathrm{Cu}$ electrolysis in the powder range formation on the shape, crystal structure, SSA and PSD characteristics.

\section{Experimental}

\subsection{Electrochemical production of $\mathrm{Cu}$ powders}


Copper powders were produced by the potentiostatic regime of electrolysis from 0.10 $\mathrm{M} \mathrm{CuSO}_{4}$ in $0.50 \mathrm{M} \mathrm{H}_{2} \mathrm{SO}_{4}$ at overpotentials of 625,925 and $1000 \mathrm{mV}$, with a quantity of the electricity of $10 \mathrm{~mA} \mathrm{~h} \mathrm{~cm}{ }^{-2}$. The processes of electrolysis were performed in an open cell of cylindrical shape at the room temperature. The working, reference and counter electrodes were of pure copper. The working electrode was of a cylindrical shape, a length of $2.0 \mathrm{~cm}$ and a diameter of $0.8 \mathrm{~mm}$ (the overall surface area $0.50 \mathrm{~cm}^{2}$ ). The counter electrode was in the form of foil and situated close to the wall of cell. The working electrode was situated in the middle of the cell, while the tip of $\mathrm{Cu}$ reference electrode was positioned at a distance of about $2 \mathrm{~mm}$ from the surface of working electrode.

2.2 The determination of the average current efficiency for hydrogen evolution reaction $\left(\eta_{\mathrm{I}, \mathrm{av}}\left(\mathrm{H}_{2}\right)\right)$

For the determination of the average current efficiency of hydrogen evolution, an electrochemical cell with the same arrangement of copper electrodes as that used for the $\mathrm{Cu}$ electrolysis was employed. The electrodes were situated under a burette with the surface facing up so that the total amount of hydrogen evolved during the electrolysis processes went into the burette. In these measurements, the surface area of $\mathrm{Cu}$ electrode was $0.63 \mathrm{~cm}^{2}$. During the electrolysis process, the volume of evolved hydrogen $V\left(\mathrm{H}_{2}\right)$ and the current of electrolysis $I$ after a time $t$ were recorded. Then, after graphical integration $I-t$, the current efficiency for hydrogen evolution $\eta_{\mathrm{I}}\left(\mathrm{H}_{2}\right)$ in a time $t$ was determined according to Eq. (1):

$$
\eta_{\mathrm{I}}\left(\mathrm{H}_{2}\right)=\frac{V\left(\mathrm{H}_{2}\right)}{\mu\left(\mathrm{H}_{2}\right) \int_{0}^{t} I \mathrm{~d} t}
$$

where

$$
\mu\left(\mathrm{H}_{2}\right)=\frac{V}{n F}=\frac{24120 \mathrm{~cm}^{3}}{2 \times 26.8 \mathrm{Ah}}=450 \frac{\mathrm{cm}^{3}}{\mathrm{Ah}}
$$

and $n F$ is the number of Faradays per mole of consumed ions and $V$ is the molar volume of a gas at a temperature of $21.0{ }^{\circ} \mathrm{C}$ (i.e. $24120 \mathrm{~cm}^{3}$ ). The average current efficiency of hydrogen evolution, $\eta_{\mathrm{I}, \mathrm{av}}\left(\mathrm{H}_{2}\right)$ is determined after graphical integration $\eta_{\mathrm{I}}\left(\mathrm{H}_{2}\right)-t$ as $\eta_{\mathrm{I}, \mathrm{av}}\left(\mathrm{H}_{2}\right)=(1 / t) \int_{0}^{t} \eta_{\mathrm{I}}\left(\mathrm{H}_{2}\right) \mathrm{d} t$.

The specification of the experimental procedure for the determination of the average current efficiency of hydrogen evolution is given by Nikolić et al. [23].

\subsection{Characterization of the $\mathrm{Cu}$ particles produced by electrolysis}

Morphologies of potentiostatically produced particles were characterized by the technique of scanning electron microscopy (SEM) using TESCAN Digital Microscopy model VEGA3, Brno, Czech Republic.

The XRD (X-ray diffraction) analysis of $\mathrm{Cu}$ particles was performed using the Rigaku Ultima IV diffractometer (Rigaku Co. Ltd., Tokyo, Japan), with $\mathrm{CuK}_{\alpha}$ radiation $(0.154178$ 
$\mathrm{nm}$ ) in $2 \theta$ range from 30 to $95^{\circ}$. The preferred orientation of $\mathrm{Cu}$ particles was estimated by the determination of the "Texture Coefficient", $T C(h k l)$ and the „Relative Texture Coefficient", $R T C(h k l)$ in a following way $[21,22,24]$ :

The ratio of intensity of $(h k l)$ reflection to the sum of all intensities of the recorded reflections, $R(h k l)$, (in \%) is calculated according to Eq. (3):

$$
R(h k l)=\frac{I(h k l)}{\sum_{\mathrm{i}}^{4} I\left(h_{\mathrm{i}} k_{\mathrm{i}} l_{\mathrm{i}}\right)} \times 100
$$

where $I(h k l)$ is the intensity of the $(h k l)$ reflection, in cps, and $\sum_{\mathrm{i}}^{4} I\left(h_{\mathrm{i}} k_{\mathrm{i}} l_{\mathrm{i}}\right)$ is the sum of all intensities of the recorded reflections, in cps, for the particles under consideration.

The "Texture Coefficient", $T C(h k l)$, for every $(h k l)$ reflection is defined by Eq. (4):

$$
T C(h k l)=\frac{R(h k l)}{R_{\mathrm{s}}(h k l)}
$$

where $R_{\mathrm{s}}(h k l)$ is defined in the same way as given by Eq. (3), but is related to the $\mathrm{Cu}$ standard (04-0836). This coefficient gives accurate quantitative information about the absolute intensity of the reflection.

Finally, the "Relative Texture Coefficient", $R T C(h k l)$ is defined by Eq. (5):

$$
R T C(h k l)=\frac{T C(h k l)}{\sum_{\mathrm{i}}^{4} T C\left(h_{\mathrm{i}} k_{\mathrm{i}} l_{\mathrm{i}}\right)} \times 100
$$

The $R T C(h k l)$ coefficient defines the intensity of the $(h k l)$ reflection relative to the standard (included in the $T C$ values).

Phase analysis was done by using the Powder Cell software (version 2.4). The average crystallite size was calculated on the basis of the full-width at half-maximum intensity (FWHM) of the (111), (200), (220) and (311) reflection of fcc $\mathrm{Cu}$ by applying Scherrer's formula and the lattice strain of electrodeposited powders was estimated from Williamson-Hall plots [22, 25, 26].

The specific surface area of powders was determined by use of MALVERN Instruments MASTERSIZER 2000 device. The values of the specific surface area (SSA) are obtained using the "Malvern Software" which control the apparatus operation and processing the obtained data.

\section{Results and discussion}

\subsection{Polarization study of $\mathrm{Cu}$ electrodeposition system}

Polarization curve for $\mathrm{Cu}$ electrodeposition from $0.10 \mathrm{M} \mathrm{CuSO}_{4}$ in $0.50 \mathrm{M} \mathrm{H}_{2} \mathrm{SO}_{4}$ is shown in Fig. 1. The plateau of the limiting diffusion current density is defined by vertical lines on this Figure, from which can be seen that it corresponds to the range of overpotentials between 300 and $750 \mathrm{mV}$. After an overpotential of $750 \mathrm{mV}$ (the inflection point), the current density increased sharply with the further increase in the overpotential. 


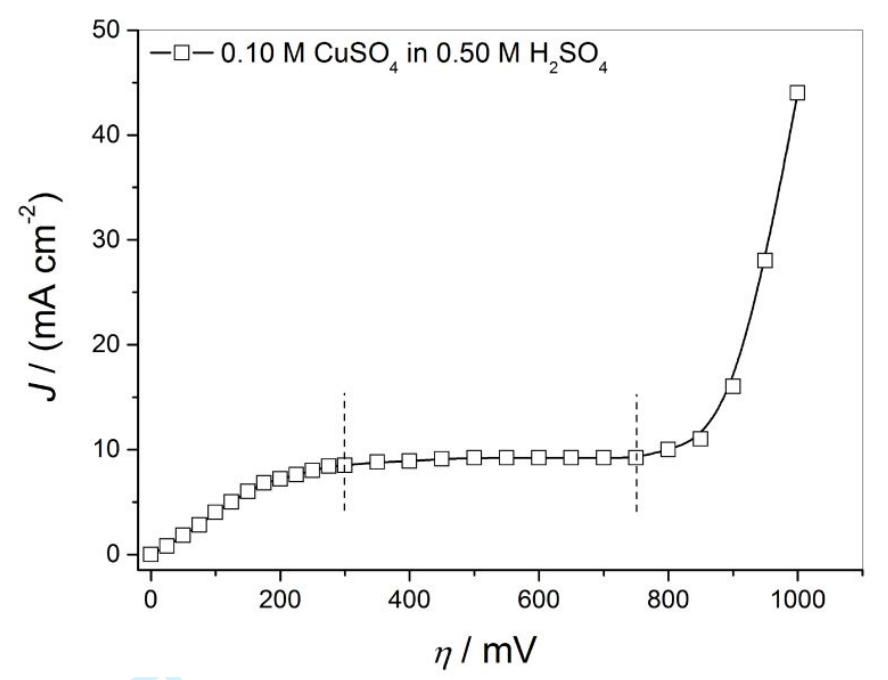

Figure 1. Polarization curve for $\mathrm{Cu}$ electrodeposition from $0.10 \mathrm{M} \mathrm{CuSO}_{4}$ in $0.50 \mathrm{M} \mathrm{H}_{2} \mathrm{SO}_{4}$.

3.2 Morphological study of the electrochemically produced $\mathrm{Cu}$ powder particles

In the potentiostatic regime of electrolysis, $\mathrm{Cu}$ in the powder form is obtained at overpotentials belonging to the plateau of the limiting diffusion current density and at the higher ones. Figure 2 shows the powdered forms obtained at an overpotential of $625 \mathrm{mV}$ (the plateau of the limiting diffusion current density). The 3D (three dimensional) pine-like dendrites were the dominant form obtained by electrolysis at this overpotential (Fig. 2a). The 3D pine-like dendrites were constructed from the corncob-like elements (Fig. 2b), while they were constructed from small agglomerates of approximately spherical $\mathrm{Cu}$ grains (Fig. 2c). The size of grains in these agglomerates was about $1 \mu \mathrm{m}$. The cauliflower-like particles constructed from agglomerates of approximately spherical grains, and individual precursors of holes originating from the detached hydrogen bubbles were also formed by electrolysis at $625 \mathrm{mV}$ (Fig. 2d). There is no any difference in the shape of dendritic particles obtained by the electrolysis process and those after their removing from the electrode surface (Fig. 2e and f). 


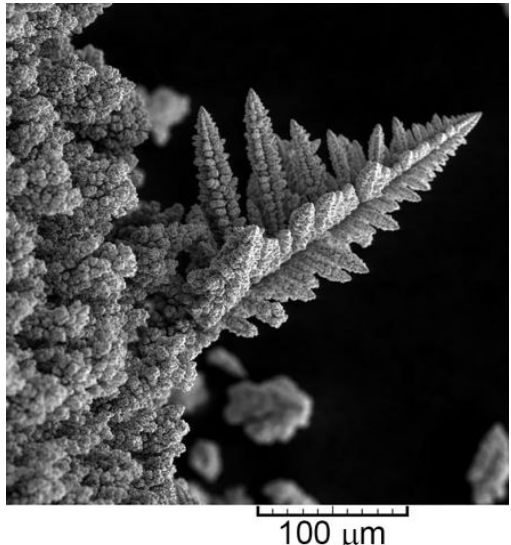

a)

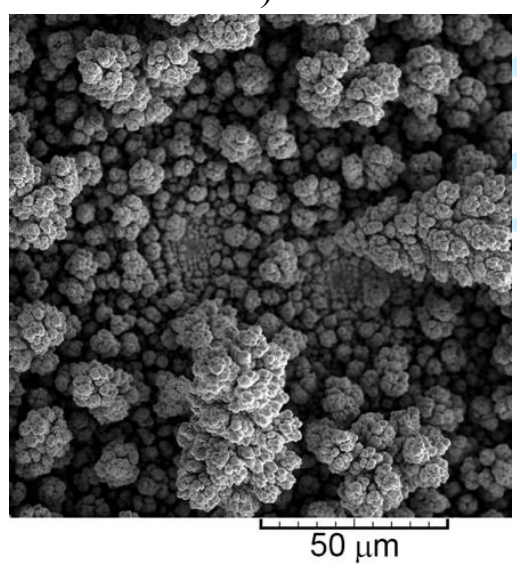

d)

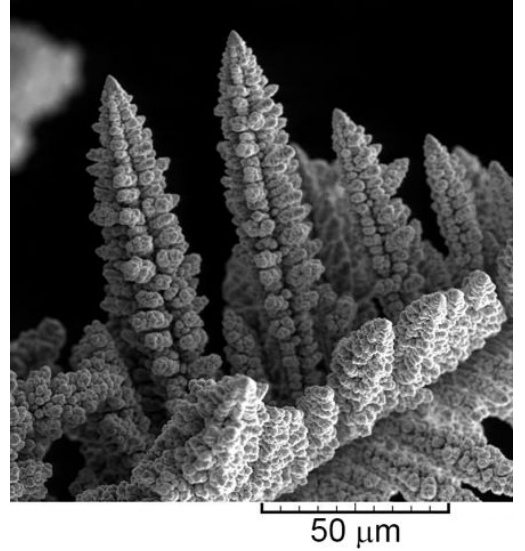

b)

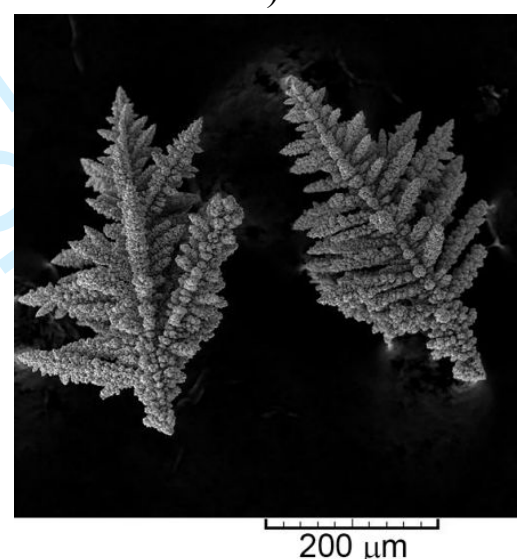

e)

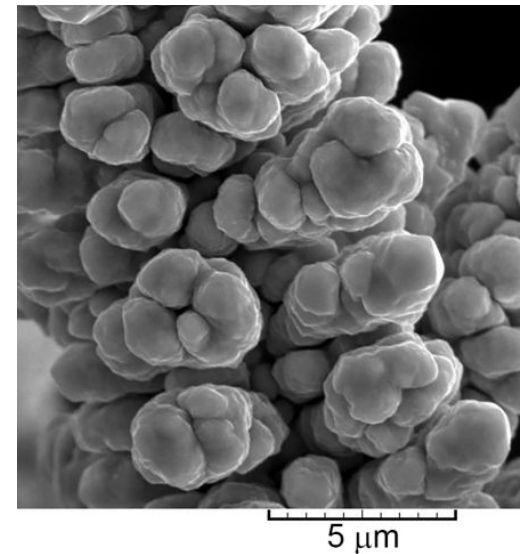

c)

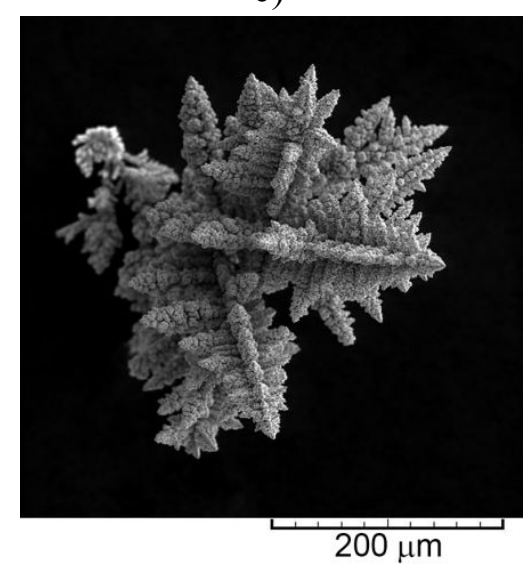

f)

Figure 2. Morphologies of powdered $\mathrm{Cu}$ obtained by electrolysis at an overpotential of 625 $\mathrm{mV}: \mathrm{a}$ ) the dendrite, and components of it: b) the corncob-like forms, and c) agglomerates of approximately spherical grains, d) cauliflower-like agglomerates of $\mathrm{Cu}$ grains and precursors of holes formed from the detached hydrogen bubbles, e) and f) the dendritic particles.

Morphologies of powdered $\mathrm{Cu}$ obtained at overpotentials of 925 and $1000 \mathrm{mV}$ in the zone of the fast increase of the current density with overpotential are shown in Figs. 3 and 4, respectively. At the both overpotentials, the honeycomb-like structures were formed (Fig. 3a and Fig. 4a). These structures are formed in the conditions of vigorous hydrogen evolution [1, 23], and their main elements are: holes formed from detached hydrogen bubbles (Fig. 3b and Fig. 4b) and cauliflower-like agglomerates of $\mathrm{Cu}$ grains formed around them (Fig. 3c and Fig. $4 \mathrm{c})$. The cauliflower-like agglomerates of $\mathrm{Cu}$ grains were very disperse and constructed from small agglomerates of approximately spherical grains, mutually separated by irregular channels (Fig. 3c and d, and Fig. 4c and d). The size of grains in these agglomerates was about $200 \mathrm{~nm}$. The particles obtained by removing the deposits from the honeycomb-like electrodes are shown in Fig. 3e and f, for the deposit electrodeposited at $925 \mathrm{mV}$, and in Fig. $4 \mathrm{e}$ and $\mathrm{f}$, for the deposit electrodeposited at $1000 \mathrm{mV}$. Inhibition of dendritic growth and formation of the cauliflower-like particles are clearly visible from these Figures. 


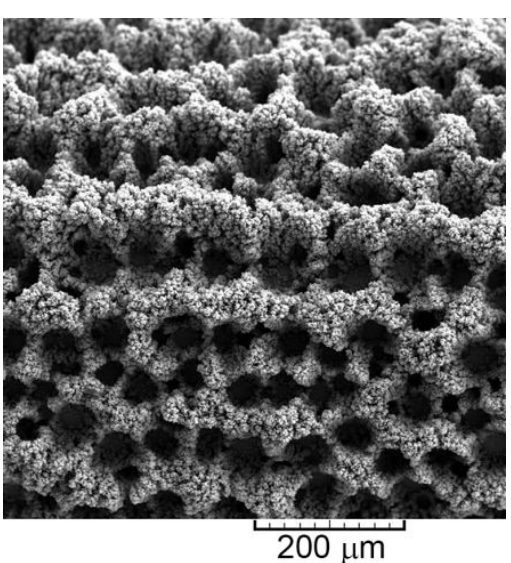

a)

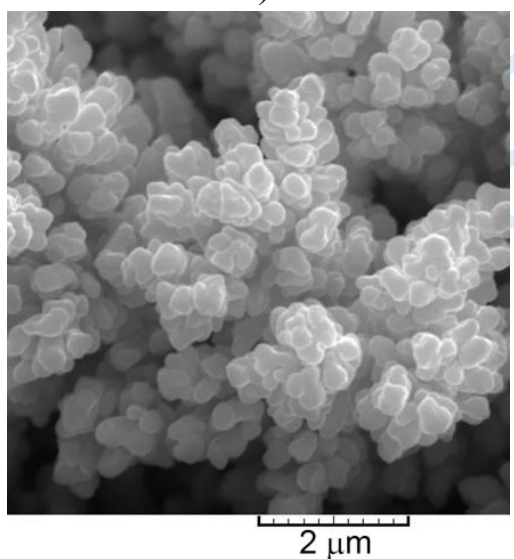

d)

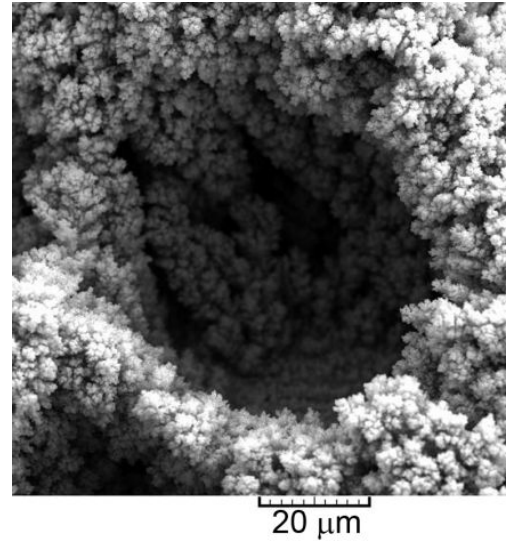

b)

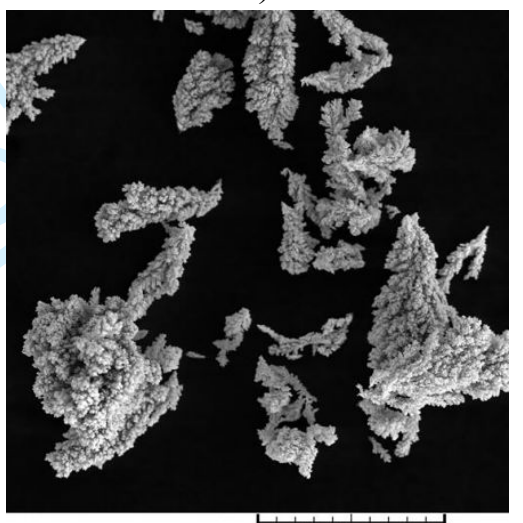

$100 \mu \mathrm{m}$

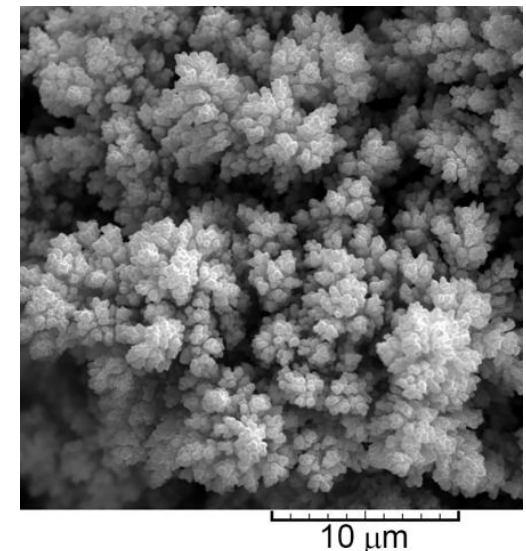

c)

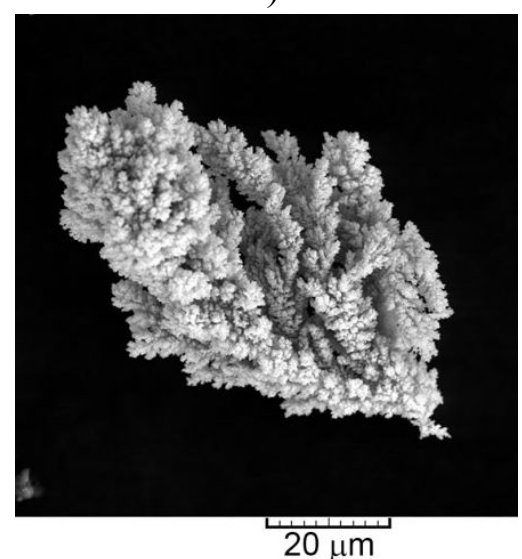

f)

Figure 3. Morphologies of $\mathrm{Cu}$ powdered deposits obtained by electrolysis at an overpotential of $925 \mathrm{mV}$ : a) the honeycomb-like structure, and components of it: b) hole formed from the detached hydrogen bubble, c) cauliflower-like particles formed among holes, and d) small agglomerates constructed from approximately spherical grains, e) and f) the particles obtained by removing the deposits after the finished electrolysis process. 


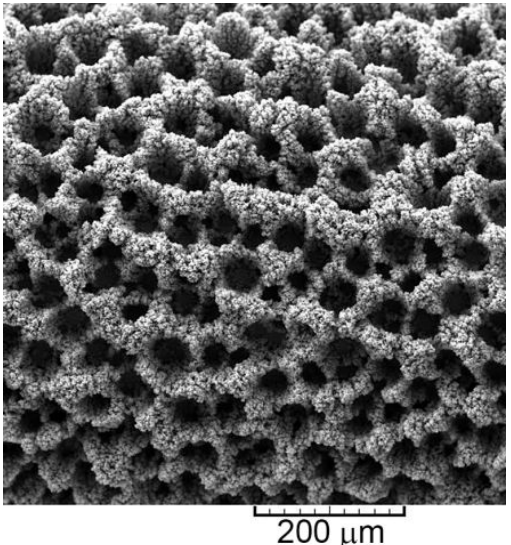

a)

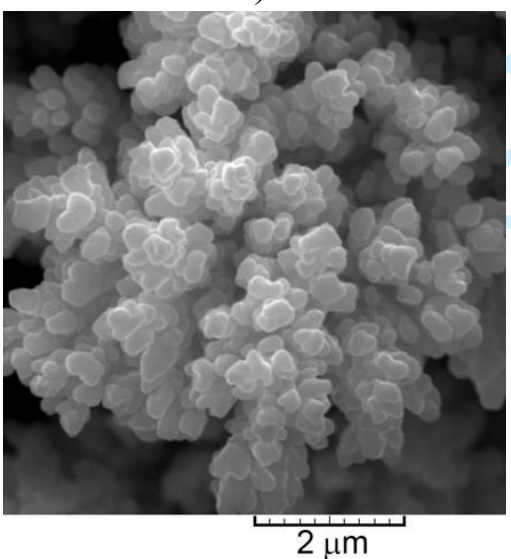

d)

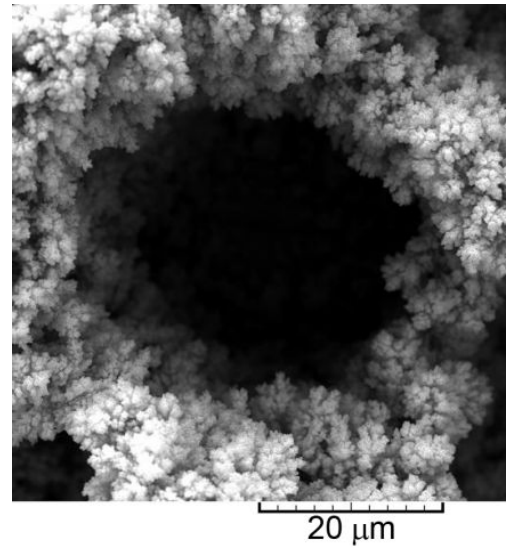

b)

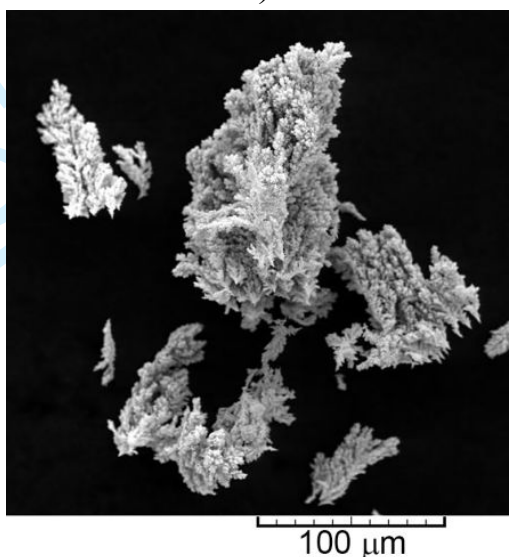

e)

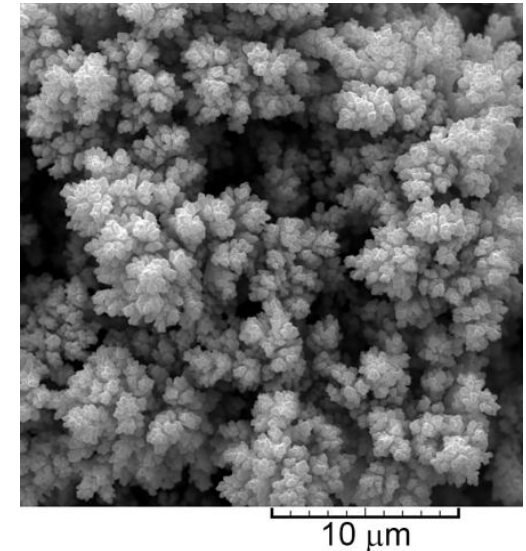

c)

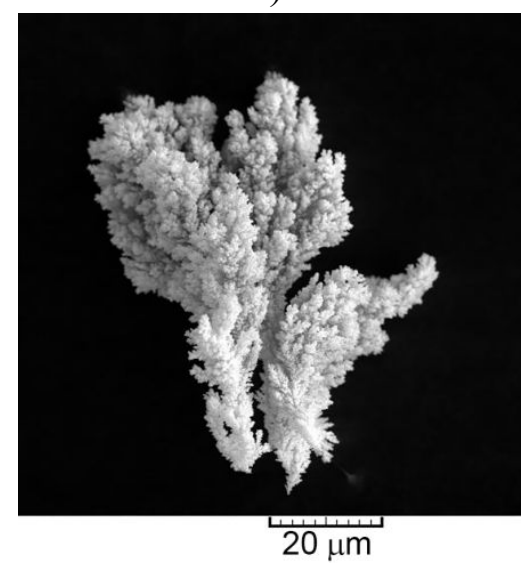

f)

Figure 4. Morphologies of $\mathrm{Cu}$ powdered deposits obtained by electrolysis at an overpotential of $1000 \mathrm{mV}$ : a) the honeycomb-like structure, and components of it: b) hole formed from the detached hydrogen bubble, c) cauliflower-like particles formed among holes, and d) small agglomerates constructed from approximately spherical grains, e) and f) the particles obtained by removing the deposits after the finished electrolysis process.

\subsection{Crystal orientation and structure of $\mathrm{Cu}$ powder particles}

\subsubsection{The preferred orientation of the formed $\mathrm{Cu}$ particles}

The XRD patterns of the powder particles obtained at overpotentials of 625, 925 and $1000 \mathrm{mV}$ together with $\mathrm{Cu}$ standard (04-0836) are shown in Fig. 5. The peaks at $2 \theta$ angles of $43.3^{\circ}, 50.4^{\circ}, 74.1^{\circ}$ and $89.9^{\circ}$ correspond to (111), (200), (220) and (311) crystal planes confirming face centered cubic (fcc) crystal lattice of $\mathrm{Cu}$. In all XRD patterns, the crystallites were dominantly oriented in the (111) plane due to lower surface energy of this plane in relation to the other planes $[27,28]$. The preferred orientation of the produced particles was estimated by the analysis of peak intensity ratios $((111) /(200),(111) /(220)$ and $(111) /(311))-$ the fast estimation, and by the determination of $T C(h k l)$ and $R T C(h k l)$ coefficients - the precise estimation. 


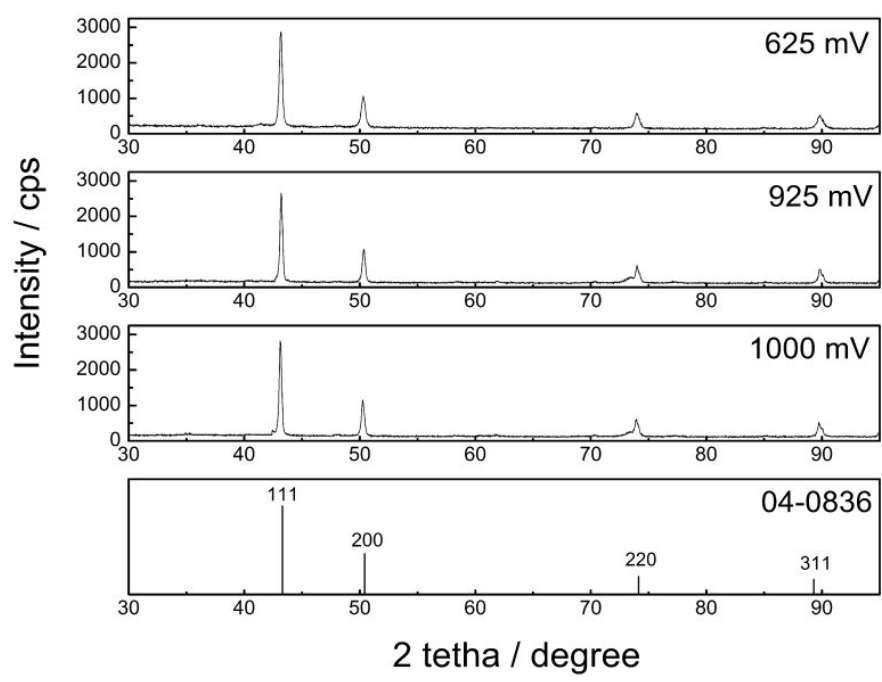

Figure 5. The XRD patterns of $\mathrm{Cu}$ particles obtained at the overpotentials of 625,925 and $1000 \mathrm{mV}$, and $\mathrm{Cu}$ standard (04-0836).

In Table 1 are given the values of the peak intensity ratios $(111) /(200),(111) /(220)$ and (111)/(311) calculated for the given particles and for $\mathrm{Cu}$ standard. Analysis of the presented ratios indicates that there are no larger deviations than those for the $\mathrm{Cu}$ standard suggesting the random orientation of crystallites in all powder particles.

Table 1. Ratios of the intensities of the diffraction peaks for the analyzed powders and the $\mathrm{Cu}$ standard: $\mathrm{Cu}(625)$ - powder produced at $625 \mathrm{mV} ; \mathrm{Cu}(925)$ - powder produced at $925 \mathrm{mV}$ and $\mathrm{Cu}(1000)$ - powder produced at $1000 \mathrm{mV}$.

\begin{tabular}{|c|c|c|c|}
\hline \multirow{2}{*}{$\begin{array}{c}\text { The Type } \\
\text { of powder particles }\end{array}$} & \multicolumn{3}{|c|}{ Ratio of Intensities: } \\
\cline { 2 - 4 } & $(111) /(200)$ & $(111) /(220)$ & $(111) /(311)$ \\
\hline $\mathrm{Cu}(625)$ & 2.7 & 4.9 & 5.5 \\
\hline $\mathrm{Cu}(925)$ & 2.5 & 4.3 & 5.2 \\
\hline $\mathrm{Cu}(1000)$ & 2.5 & 4.6 & 5.4 \\
\hline $\mathrm{Cu}$ standard $(04-0836)$ & 2.2 & 5.0 & 5.9 \\
\hline
\end{tabular}

The values of $T C(h k l)$ and $R T C(h k l)$ coefficients for the same powders are given in Table 2. The values of $T C$ coefficients above 1 and $R T C$ coefficients above $25 \%$ (four reflections in the XRD patterns were analyzed in this study) indicate the existence of the preferred orientation in the particles $[21,22,24]$. Although the strict analysis of these coefficients can indicate the existence of very mild (220) and (311) preferred orientation, the obtained values are still very close to 1 and $25 \%$ confirming the random oriented crystallites in the particles. 
Table 2. Texture calculations for $\mathrm{Cu}$ powders obtained by potentiostatically at overpotentials of 625,925 and $1000 \mathrm{mV}(625 \mathrm{mV}-625,925 \mathrm{mV}-925,1000 \mathrm{mV}-1000, \mathrm{~s}-\mathrm{Cu}$ standard $)$.

\begin{tabular}{|c|c|c|c|c|c|c|c|c|c|c|}
\hline \multirow{2}{*}{ Plane $(h k l)$} & \multicolumn{3}{|c|}{$R$ (in \%) } & \multirow{2}{*}{$R_{\mathrm{S}}$ (in \%) } & \multicolumn{4}{|c|}{$T C$} & \multicolumn{3}{c|}{$R T C$ (in \%) } \\
\cline { 2 - 7 } & $R_{625}$ & $R_{925}$ & $R_{1000}$ & & $T C_{625}$ & $T C_{925}$ & $T C_{1000}$ & $R T C_{625}$ & $R T C_{925}$ & $R T C_{1000}$ \\
\hline$(111)$ & 56.9 & 54.7 & 55.2 & 54.6 & 1.04 & 1.00 & 1.01 & 25.7 & 24.0 & 24.6 \\
\hline$(200)$ & 21.2 & 22.0 & 22.5 & 25.1 & 0.845 & 0.876 & 0.896 & 20.1 & 21.0 & 21.8 \\
\hline$(220)$ & 11.6 & 12.7 & 12.0 & 10.9 & 1.06 & 1.16 & 1.10 & 26.2 & 27.8 & 26.8 \\
\hline$(311)$ & 10.3 & 10.6 & 10.3 & 9.4 & 1.10 & 1.13 & 1.10 & 27.2 & 27.1 & 25.8 \\
\hline
\end{tabular}

The values of the average crystallite size and lattice strain obtained for the $\mathrm{Cu}$ particles produced at 625,925 and $1000 \mathrm{mV}$ are given in Table 3. The obtained values for the average crystallite size clearly point out nanostructural character of the produced $\mathrm{Cu}$ particles. According to expectation, the decrease of the average crystallite size was observed with an increase in electrolysis overpotential. It is necessary to note that the values obtained at 925 and $1000 \mathrm{mV}$ were very close to each others.

Table 3. The values of the average crystallite size, the lattice strain, the average current efficiency of hydrogen evolution, $\eta_{\mathrm{I}, \mathrm{av}}\left(\mathrm{H}_{2}\right)$, and the specific surface area (SSA) obtained for the powders produced at overpotentials of 625,925 and $1000 \mathrm{mV}$.

\begin{tabular}{|c|c|c|c|c|}
\hline$\eta / \mathrm{mV}$ & Crystallite size $/ \mathrm{nm}$ & Lattice strain $\times 10^{-3}$ & $\eta_{\mathrm{I}, \mathrm{av}}\left(\mathrm{H}_{2}\right) / \%$ & $\mathrm{SSA} / \mathrm{m}^{2} \mathrm{~g}^{-1}$ \\
\hline 625 & 100 & 3.061 & 2.0 & 0.0287 \\
\hline 925 & 84 & 2.114 & 36.6 & 0.084 \\
\hline 1000 & 81 & 2.095 & 46.8 & 0.0952 \\
\hline
\end{tabular}

\subsubsection{Crystal structure of $\mathrm{Cu}$ dendrites}

The patterns obtained at an overpotential of $625 \mathrm{mV}$, in diffusion-controlled system, are dendrites (Fig. 2). A dendrite is a crystal with a tree-like branching structure which is characterised by growth of the stalk and branches along preferred crystallographic direction. The planar dendrites are twin crystals, and a twin plane re-entrant edge (TPRE) mechanism can account qualitatively for the behaviour of all the two-dimensional dendrites [29, 30]. The essence of this mechanism lies in the ability of twin boundaries to provide re-entrant grooves or two-dimensional nucleation sites, which are self-perpetuating. The twinning plane in fcc crystal is (111), and nuclei containing two or more twin planes, have six re-entrant grooves, $60^{\circ}$ apart, located alternatively first at one twin plane and then the other. Thus, the main stem of a dendrite is formed by stacked octahedra (Fig. 6a) undergoing longitudinal propagation in the octahedral plane (111). There are favoured re-entrant growth sites at six $<211>$ directions, and rapid growth takes place in these directions. Most important, these favoured growth sites will not disappear and growth can continue indefinitely.

Dendrites also grow in thickness, by layer growth mechanism, and as a consequence, the facets appear on the main face of a dendrite [22]. The 111 facets on the main face arise passing throughout from the stem and it is likely the dendrite branch in $<111>$ direction, so that the main stem and primary branches make an angle of nearly $90^{\circ}$ (Fig. 2a). In this way, 
dendrites grow in $<211>$ and $<111>$ directions, so they have 3D appearance. Furthermore, except the main stem, all the branches are formed by stacked octahedrons which have six reentrant grooves and grow in six $<211>$ directions (Fig. 6b). Consequently, the branches look like a corn, as seen in Fig. 6c.

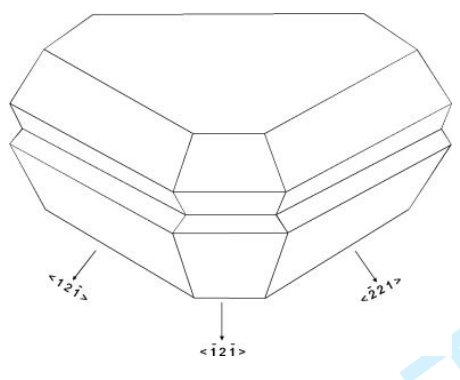

a)

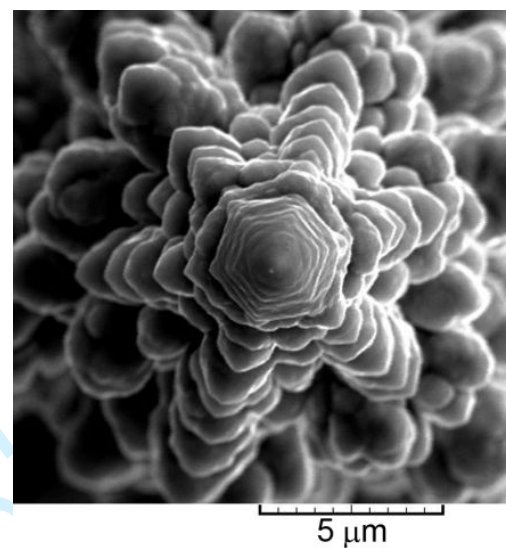

b)

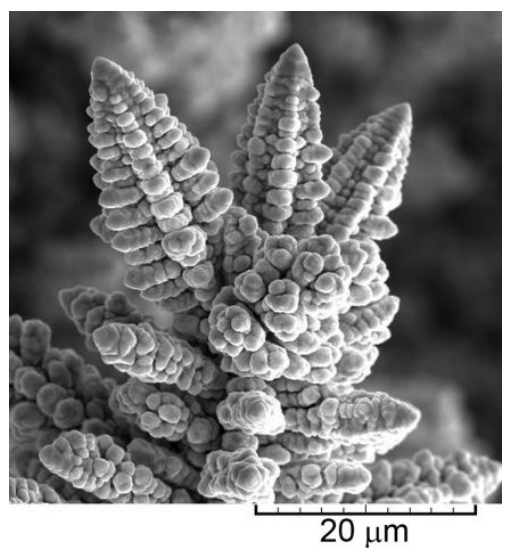

c)

Figure 6. a) stacked octahedra, b) and c) dendrites of $\mathrm{Cu}$ obtained by electrolysis at an overpotential of $625 \mathrm{mV}: \mathrm{b}$ ) top view of dendrite, and c) side view of dendrite branches.

\subsection{Discussion of the presented results}

In the dependence of conditions of electrolysis, the two types of particles were formed: dendrites and cauliflower-like particles. The different forms of the particles are caused by the appearance of hydrogen evolution reaction as parallel reaction to $\mathrm{Cu}$ electrolysis at the high overpotentials. Hydrogen evolution commences at some overpotential belonging to the plateau of the limiting diffusion current density and intensifies with the increase of overpotential. For this electrolyte, the critical overpotential for the beginning of hydrogen evolution reaction is estimated at $590 \mathrm{mV}$ [31]. Figure 7 shows the volume of evolved hydrogen, $V\left(\mathrm{H}_{2}\right)$ (Fig. 7a) and the current of electrolysis, $I$ (Fig. 7b) on the time, $t$, obtained at overpotentials of 625,925 and $1000 \mathrm{mV}$. The dependencies of the current efficiency of hydrogen evolution, $\eta_{\mathrm{I}}\left(\mathrm{H}_{2}\right)$, on $t$ derived from the data from Fig. $7 \mathrm{a}$ and $\mathrm{b}$ using Eq. (1) are presented in Fig. 7c. The average current efficiencies of hydrogen evolution, $\eta_{\mathrm{I}, \mathrm{av}}\left(\mathrm{H}_{2}\right)$ are obtained by the graphical integration of these dependencies and obtained values are added to Table 3. Intensification of hydrogen evolution with the increase of overpotential is clearly visible from this Table. 


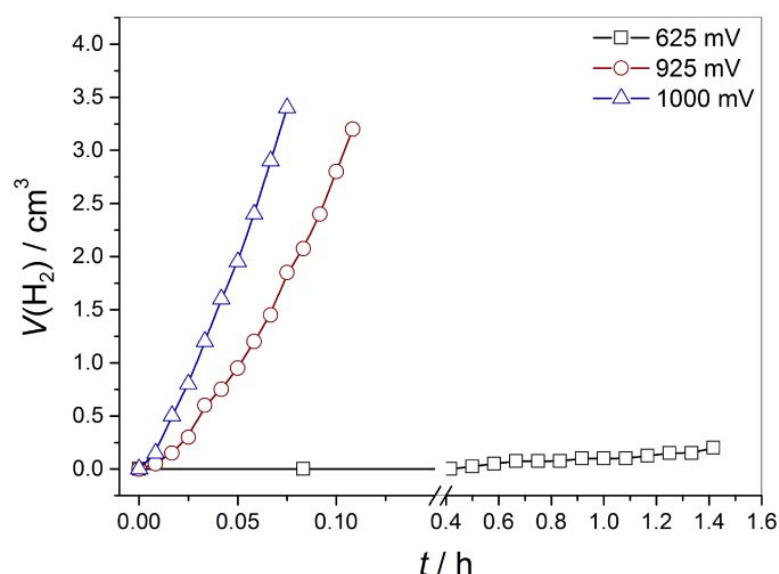

a)

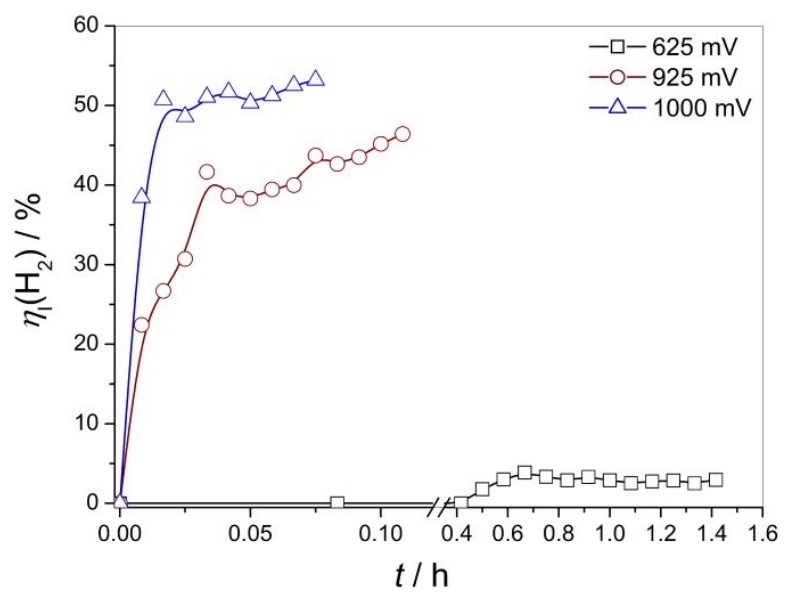

c)

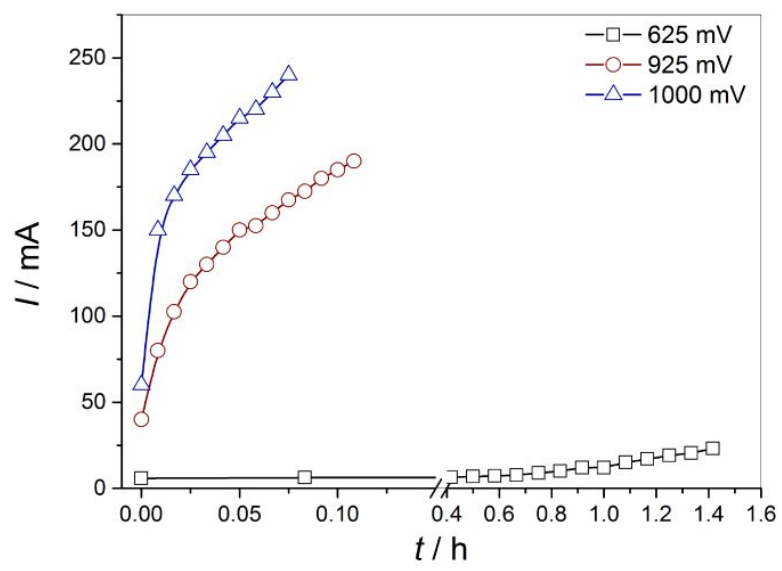

b)

Figure 7. The dependencies of: a) the volume of evolved hydrogen $\left(V\left(\mathrm{H}_{2}\right)\right)$, b) the current of electrolysis $(I)$, and c) the current efficiency of hydrogen evolution, $\eta_{\mathrm{I}}\left(\mathrm{H}_{2}\right)$ on time $(t)$ obtained at overpotentials of 625,925 and $1000 \mathrm{mV}$.

In this way, formation of the different forms of the particles can be explained as follows: very non-uniformed electrode surface was formed by the process of electrolysis at an overpotential of $625 \mathrm{mV}$ (Fig. 2). Aside from dendrites (Fig. 2a), as the most dominant shape of the particles, the cauliflower-like agglomerates of $\mathrm{Cu}$ grains and individual precursors of holes originating from the detached hydrogen bubbles (Fig. 2d) were also formed at this overpotential. The amount of evolved hydrogen which corresponded to $\eta_{\mathrm{I}, \mathrm{av}}\left(\mathrm{H}_{2}\right)$ of $2.0 \%$ was not enough to achieve any effect on the hydrodynamic conditions in the near-electrode layer. The growth of these particles occurred inside the diffusion layer of the macroelectrode, and the electrolysis process was primarily controlled by the diffusion of ions to the electrode surface, rather than the kinetics of the electrodeposition [1, 32].

On the other hand, hydrogen evolution at overpotentials of 925 and $1000 \mathrm{mV}$ was enough vigorous to achieve the strong effect on the hydrodynamic conditions in the nearelectrode layer. The values of $\eta_{\mathrm{I} \text {,av }}\left(\mathrm{H}_{2}\right)$ of 36.6 and $46.8 \%$ were considerably above the critical value of $10.0 \%$ [1] leading to the change of hydrodynamic conditions in the nearelectrode layer, and an overpotential corresponding to the inflection point at the polarization 
curve just corresponds to this value. As result of vigorous hydrogen evolution, deposits denoted as the honeycomb-like structures with uniform distribution of holes formed from the detached hydrogen bubbles and cauliflower-like agglomerates of $\mathrm{Cu}$ grains among them are formed. The main consequence of vigorous hydrogen evolution is inhibition of dendritic growth. Namely, vigorous hydrogen evolution causes stirring of the electrolyte in the nearelectrode layer leading to the decrease in the thickness of the diffusion layer and the increase in the limiting diffusion current density value. As a result of these processes, the decrease in the degree of diffusion control in relation to conditions without and with insufficient hydrogen evolution to achieve any effect on the hydrodynamic conditions in the nearelectrode layer is realized, and the growth of dendrites was completely inhibited.

The concept of "effective overpotential" is proposed to explain inhibition of dendritic growth and formation of the cauliflower-like particles (Figs. 3 and 4) instead of the dendrites (Fig. 2), that can be considered as follows [1, 23]: in the conditions of vigorous hydrogen evolution, the electrodeposition process occurs at an overpotential which is effectively lower than that specified, and this overpotential is denoted as "effective" in a deposition process. From the morphological point of view, this means that the morphologies of metal deposits become similar to those obtained at some lower overpotentials at which hydrogen evolution does not occur or is very slow. Formation of the cauliflower-like particles instead of dendrites really confirms that there is a lower degree of the diffusion control at 925 and $1000 \mathrm{mV}$ than at $625 \mathrm{mV}$.

The XRD analysis (Fig. 5) showed that crystallites of $\mathrm{Cu}$ were random oriented in the both types of the particles. This random orientation can be explained by the existence of the spherical morphology in the both types of particles. Namely, in spite of completely different shapes of the particles at the macro level (dendrites and cauliflower-like particles), the micro structure of the obtained particles was very similar. The both types of the particles consisted of the small agglomerates of approximately spherical grains (Fig. 2c, Fig. 3d and Fig. 4d). Formation of the particles with the random orientation of crystallites in them can be explained from electrochemical point of view through analysis of the rate of electrochemical processes ( $J_{\mathrm{o}}$ values, where $J_{\mathrm{o}}$ is the exchange current density) as follows: $\mathrm{Cu}$ belongs to the group of the intermediate metals with the medium $J_{\mathrm{o}}$ values and the lower overpotentials for hydrogen discharge than the normal metals. For this electrolyte, the $J_{\mathrm{o}}$ is $0.11 \mathrm{~mA} \mathrm{~cm}^{-2}$ [31], and it is valid $J_{\mathrm{o}}<J_{\mathrm{L}}$, where $J_{\mathrm{L}}$ is the limiting diffusion current density. As a result of this, the random orientation was observed in $\mathrm{Cu}$ particles. The strong (111) preferred orientation was observed in the particles belonging to the group of normal metals, such as $\mathrm{Ag}[21,22]$ and $\mathrm{Pb}$ [33], which are characterized by the very high $J_{\mathrm{o}}$ values $\left(J_{\mathrm{o}} \gg>J_{\mathrm{L}}\right.$; very fast electrochemical processes). The absence of the spherical morphology and formation of the 2D (two dimensional) needle-like and fern-like dendrites were characteristic forms of powder particles of these metals. On the other hand, the random orientation was observed for nickel particles obtained by the electrolysis process [33]. Ni belongs to the group of the inert metals, characterized by low values of both $J_{\mathrm{o}}$ and overpotential for hydrogen evolution reaction. The spongy-like particles constructed from holes formed by the detachment of hydrogen bubbles surrounded by the cauliflower-like agglomerates of Ni grains were formed by Ni electrolysis 
[33]. These cauliflower-like agglomerates were consisted of small agglomerates of approximately spherical $\mathrm{Ni}$ grains.

The further comparison of the obtained $\mathrm{Cu}$ powder particles was performed by the analysis of the specific surface area (SSA) and the particle size distribution (PSD) of the produced particles. The SSA values obtained at overpotentials of 625, 925 and $1000 \mathrm{mV}$ are added in Table 3. It can be seen that the SSA values increase with increasing overpotential of electrolysis. Simultaneously, the obtained values for the powders synthesized at 925 and 1000 $\mathrm{mV}$ were very close each other and more than three times larger than the value obtained at $625 \mathrm{mV}$. It is understandable due to the similar morphology of the particles formed at 925 and $1000 \mathrm{mV}$ in the conditions of vigorous hydrogen evolution.

The particle size distribution (PSD) curves obtained for the considered particles are shown in Fig. 8. From Fig. 8, it can be seen that the size of particles decreases with increasing the overpotential of electrolysis. The most uniform distribution of the particles is obtained for those produced at $1000 \mathrm{mV}$. For the particles produced at 625 and $925 \mathrm{mV}$, it is noticeable the presence of particles smaller $(625 \mathrm{mV}$ ) and larger (both 625 and $925 \mathrm{mV}$ ) than those occupying the maximum volume ratios at the PSD curves. At $625 \mathrm{mV}$, the presence of smaller particles can be ascribed to formation of cauliflower-like particles (Fig. 2d), while formation of the larger particles is probably result of formation of very branchy 3D dendrites like that shown in Fig. 2f. On the other hand, due to very vigorous hydrogen evolution, the particles of different size can be obtained (Fig. 3e). Anyway, the more intensive hydrogen evolution reaction, the more uniform distribution of the particles is observed. In this way, it is shown useful benefit of hydrogen evolution reaction on the shape, size and distribution of $\mathrm{Cu}$ particles.

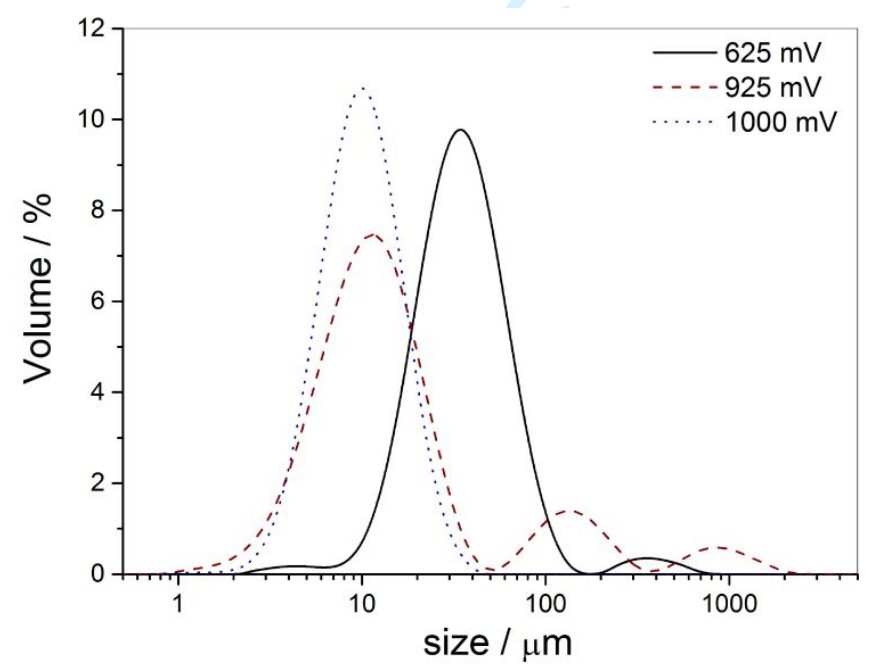

Figure 8. The particle size distribution (PSD) curves obtained for the particles produced at overpotentials of 625,925 and $1000 \mathrm{mV}$.

\section{Conclusions}

Copper powders were produced by electrolysis in the potentiostatic mode in the conditions without and with a quantity of evolved hydrogen enough to achieve any effect on 
the hydrodynamic conditions in the near-electrode layer. The two types of the particles were obtained in this way:

(a) dendrites were formed at an overpotential of $625 \mathrm{mV}$ (inside the plateau of the limiting diffusion current density), with a quantity of evolved hydrogen which corresponded to $\eta_{\mathrm{I} \text {,av }}\left(\mathrm{H}_{2}\right)$ of $2.0 \%$ insufficient to achieve any effect on the hydrodynamic conditions, and (b) cauliflower-like particles were formed at overpotentials of 925 and $1000 \mathrm{mV}$ (outside the plateau of the limiting diffusion current density), in the conditions of vigorous hydrogen evolution which corresponded to $\eta_{\mathrm{I} \text {,av }}\left(\mathrm{H}_{2}\right)$ of 36.6 and $46.8 \%$, respectively. These quantities were enough to achieve the strong effect of evolved hydrogen on the hydrodynamic conditions in the near-electrode layer.

In spite of very different macro structure, the crystallites of $\mathrm{Cu}$ were random oriented in the both types of the particles. The random orientation is ascribed to their similar micro structure. The both dendrites and cauliflower-like particles were constructed from small agglomerates of approximately spherical $\mathrm{Cu}$ grains.

The cauliflower-like particles had more than three times larger the specific surface area (SSA) than the dendritic particles. The particle size distribution (PSD) analysis showed considerable decrease in the size of particles formed in conditions of vigorous hydrogen evolution. In this way, the useful benefits of hydrogen evolution reaction as parallel reaction to $\mathrm{Cu}$ electrolysis in powder production range on some of decisive characteristics of powders, such as SSA and PSD, are shown.

Acknowledgments: This work was supported by the Ministry of Education, Science and Technological Development of the Republic of Serbia under the research project: "Electrochemical synthesis and characterization of nanostructured functional materials for application in new technologies" (Project No. 172046).

\section{References}

[1] POPOV K I, DJOKIĆ S S, NIKOLIĆ N D, JOVIĆ V D. Morphology of Electrochemically and Chemically Deposited Metals [M]. New York: Springer, 2016.

[2] NIKOLIĆ N D, STEVANOVIĆ S I, BRANKOVIĆ G. Nucleation and the early stages of growth of lead onto copper electrodes from the dilute electrolytes [J]. Transactions of Nonferrous Metals Society of China, 2016, 26: 3274-3282.

[3] ZHOU Hai-hui, LIAO Zuo-wei, FANG Chen-xu, LI Huan-xin, FENG Bin, XU Song, CAO Guo-fei, KUANG Ya-fei. Pulse electroplating of Ni-W-P coating and its anticorrosion performance [J]. Transactions of Nonferrous Metals Society of China, 2018, 28: 88-95.

[4] MAHDAVI S, ALLAHKARAM S R. Effect of bath composition and pulse electrodeposition condition on characteristics and microhardness of cobalt coatings [J]. Transactions of Nonferrous Metals Society of China, 2018, 28: 2017-2027. 
[5] KARTAL L, TIMUR S. Electrolytic production of $\mathrm{Cu}-\mathrm{Ni}$ alloys in $\mathrm{CaCl}_{2}-\mathrm{Cu}_{2} \mathrm{~S}-\mathrm{NiS}$ molten salt [J]. Transactions of Nonferrous Metals Society of China, 2018, 28: 21432150 .

[6] SEKAR R. Synergistic effect of additives on electrodeposition of copper from cyanidefree electrolytes and its structural and morphological characteristics [J]. Transactions of Nonferrous Metals Society of China, 2017, 27: 1665-1676.

[7] YUAN Liang, DING Zhi-ying, LIU Shi-jun, SHU Wei-fa, HE Ya-ning. Effects of additives on zinc electrodeposition from alkaline zincate solution $[\mathrm{J}]$. Transactions of Nonferrous Metals Society of China, 2017, 27: 1656-1664.

[8] SEAKR R. Microstructure and crystallographic characteristics of nanocrystalline copper prepared from acetate solutions by electrodeposition technique [J]. Transactions of Nonferrous Metals Society of China, 2017, 27: 1423-1430.

[9] WINAND R. Electrodeposition of Metals and Alloys - New Results and Perspectives [J]. Electrochimica Acta, 1994, 39: 1091-1105.

[10] NIKOLIĆ N D, RAKOČEVIĆ Z, POPOV K I. Structural Characteristics of Bright Copper Surfaces [J]. Journal of Electroanalytical Chemistry, 2001, 514: 56-66.

[11] OSTANINA $\mathrm{T} \mathrm{N}$, RUDOI $\mathrm{V} \mathrm{M}$, PATRUSHEV A V, DARINTSEVA A B, FARLENKOV A S. Modelling the Dynamic Growth of Copper and Zinc Dendritic Deposits under the Galvanostatic Electrolysis Conditions [J]. Journal of Electroanalytical Chemistry, 2015, 750: 9-18.

[12] NIKOLIĆ N D, PAVLOVIĆ Lj J, PAVLOVIĆ M G, POPOV K I. Morphologies of electrochemically formed copper powder particles and their dependence on the quantity of evolved hydrogen [J]. Powder Technology, 2008, 185: 195-201.

[13] ORHAN G, HAPCI G. Effect of electrolysis parameters on the morphologies of copper powder obtained in a rotating cylinder electrode cell [J]. Powder Technology, 2010, 201: $57-63$.

[14] ORHAN G, GEZGIN G G. Effect of electrolysis parameters on the morphologies of copper powder obtained at high current densities [J]. Journal of the Serbian Chemical Society, 2012, 77: 651-665.

[15] NIKOLIĆ N D, BRANKOVIĆ G, PAVLOVIĆ M G. Correlate between morphology of powder particles obtained by the different regimes of electrolysis and the quantity of evolved hydrogen [J]. Powder Technology, 2012, 221: 271-277.

[16] NEKOUEI R K, RASHCHI F, JODA N N. Effect of organic additives on synthesis of copper nano powders by pulsing electrolysis [J]. Powder Technology, 2013, 237: 554561. 
[17] NEKOUEI R K, RASHCHI F, RAVANBAKHSH A. Copper nanopowder synthesis by electrolysis method in nitrate and sulfate solutions [J]. Powder Technology, 2013, 250: 91-96.

[18] NEKOUEI R K, RASHCHI F, AMADEH A A. Using design of experiments in synthesis of ultra-fine copper particles by electrolysis [J]. Powder Technology, 2013, 237: 165-171.

[19] WANG Ming-yong, WANG Zhi, GUO Zhan-cheng. Preparation of electrolytic copper powders with high current efficiency enhanced by super gravity field and its mechanism [J]. Transactions of Nonferrous Metals Society of China, 2010, 20: 1154-1160.

[20] GERMAN R M. Powder Metallurgy Science [M] New Jersey: Metal Powder Industries Federation, 1994.

[21] AVRAMOVIĆ Lj, PAVLOVIĆ M M, MAKSIMOVIĆ V M, VUKOVIĆ M, STEVANOVIĆ J S, BUGARIN M, NIKOLIĆ N D. Comparative Morphological and Crystallographic Analysis of Electrochemically and Chemically-Produced Silver Powder Particles [J]. Metals, 2017, 7: 160.

[22] AVRAMOVIĆ Lj, IVANOVIĆ E R, MAKSIMOVIĆ V M, PAVLOVIĆ M M, VUKOVIĆ M, STEVANOVIĆ J S, NIKOLIĆ N D. Correlation between crystal structure and morphology of potentiostatically electrodeposited silver dendritic nanostructures [J]. Transactions of Nonferrous Metals Society of China, 2018, 28: 19031912.

[23] NIKOLIĆ N D, POPOV K I, PAVLOVIĆ Lj J, PAVLOVIĆ M G. The effect of hydrogen codeposition on the morphology of copper electrodeposits. I. The concept of effective overpotential [J]. Journal of Electroanalytical Chemistry, 2006, 588: 88-98.

[24] BERUBE L Ph, ESPERANCE G L. A Quantitative Method of Determining the Degree of Texture of Zinc Electrodeposits [J]. Journal of The Electrochemical Society, 1989, 136: 2314-2315.

[25] SURYANARAYANA C, NORTON M G. X-ray Diffraction, A Practical Approach [M]. New York: Springer, 1998.

[26] KAROLUS M, LAGIEWKA E. Crystallite Size and Lattice Strain in Nanocrystalline Ni-Mo Alloys Studied by Rietveld Refinement [J]. Journal of Alloys and Compounds, 2004, 367: 235-238.

[27] SIVASUBRAMANIAN R, SANGARANARAYANAN M V. Electrodeposition of Silver Nanostructures: from Polygons to Dendrites [J]. CrystEngComm, 2013, 15: 20522056. 
[28] XIA Y, XIONG Y, LIM B, SKRABALAK S E. Shape-Controlled Synthesis of Metal Nanocrystals: Simple Chemistry Meets Complex Physics? [J]. Angewandte Chemie International Edition, 2009, 48: 60-103.

[29] HAMILTON D R, SEIDENSTICKER R G. Propagation Mechanism of Germanium Dendrites [J]. Journal of Applied Physics, 1960, 31: 1165-1168.

[30] WAGNER R S. On the growth of germanium dendrites [J]. Acta Metallurgica, 1960, 8: $57-60$.

[31] NIKOLIĆ N D, ŽIVKOVIĆ P M, JOKIĆ B, PAVLOVIĆ M G, STEVANOVIĆ J S. Comparative analysis of the polarisation and morphological characteristics of electrochemically produced powder forms of the intermediate metals [J]. Macedonian Journal of Chemistry and Chemical Engineering, 2014, 33: 169-180.

[32] NIKOLIĆ N D, PAVLOVIĆ Lj J, PAVLOVIĆ M G, POPOV K I. Formation of dishlike holes and a channel structure in electrodeposition of copper under hydrogen codeposition [J]. Electrochimica Acta, 2007, 52: 8096-8104.

[33] NIKOLIĆ N D, MAKSIMOVIĆ V M, BRANKOVIĆ G, ŽIVKOVIĆ P M, PAVLOVIĆ M G. Correlation between crystal orientation and morphology of electrolytically produced powder particles: analysis of the limiting cases [J]. Materials protection, 2018, 59: 256-264. 